\title{
DESIGN AND REALIZATION OF A FEEDER PART OF THE AUTOMATED PRODUCTION LINE
}

\section{B. Fecko, T. Vince, L. Darák}

Technical University of Košice

Letná 9, 04200 Košice, Slovak Republic.

E-mail: branislav.fecko@tuke.sk, tibor.vince@tuke.sk, lukas.darak@student.tuke.sk

Purpose. The aim of the work is the design and creation of a part of an automated production line. Originality. The paper deals with the research on surveys for development of a low-cost prototype of automated production line controlled by microcontroller. Methodology. The paper proposes one of the possibilities for development automated production line using Arduino ATmega2560 platform together with the CNC shield V3, which provides the functionality of the motors. Three motors and two sensors were used for its implementation. Parts of the model were designed by CAD software and then printed using a 3D printer. Authors described whole development process starting from computer simulation of developing device, hardware design, chose and calculation of power conversion elements, development of hardware unit, design and implementation low-level and high-level software solutions and also experimental verification of derived results. Results. In this work it was solved the design of the hardware part in CAD software. The designed hardware was printed by 3D printers. The software part is solved using Arduino, which is a serial communication connected to an application created using Visual Studio. The operation of the production line was controlled via created application powered by Arduino. Practical value. Advantage of automation is to increase production speed and eliminate the need for human intervention in production, thereby increasing accuracy and eliminating the possibility of errors that a human factor could entail in the process. The disadvantage of an automated system is the complex manufacturing configuration. Therefore, such systems achieve the greatest efficiency in mass production where there is no need for frequent system setup. References 8, figures 14 .

Key words: Arduino, automation, production line, sensor, stepper motor.

\section{ПРОЕКТУВАННЯ ТА РОЗРОБКА ФІДЕРНОЇ ЧАСТИНИ АВТОМАТИЗОВАНОЇ ВИРОБНИЧОЇ ЛІНІЇ}

\section{Б. Фечко, Т. Вінсе, Л. Дарак}

Технічний університет Кошице, Словаччина

вул. Лєтня, 9, м. Кошице, 04200, Словаччина. E-mail: branislav.fecko@ tuke.sk.tibor.vince@ tuke.sk

Метою роботи є проектування та створення частини автоматизованої виробничої лінії, що призначена для транспортування та оброблювання продукції. У статті представлені результати дослідження підходів щодо розроблювання малобюджетного прототипу автоматизованої виробничої лінії, що керується мікроконтролерним пристроєм. У роботі запропонована одна з можливостей розробки автоматичної виробничої лінії з використанням платформи Arduino ATmega2560 разом з CNC shield V3, що забезпечує функціонування двигунів. Для впровадження розробки використано три крокових двигуни та два сенсори положення. Окремі частини системи було спроектовано за допомогою CAD-систем, та потім роздруковані за допомогою 3D-принтеру. Автори описали увесь процес розробки, починаючи 3 комп'ютерного моделювання розроблюваного пристрою, проектування апаратної частини, вибору і розрахунку силових перетворюючих елементів, розробки елементів апаратного забезпечення, розробки та впровадження низькорівневих та високорівневих рішень програмного забезпечення, а також закінчуючи експериментальною перевіркою отриманих результатів. У роботі було вирішено питання щодо проектування апаратної частини за допомогою $\mathrm{CAD}$-пакетів. Спроектоване апаратне забезпечення було роздруковано за допомогою 3D-принтеру. Рішення щодо програмного забезпечення були отримані на основі використання платформи Arduino, що послідовно з'єднано з програмним додатком, створеним у середовищі Visual Studio. Робота виробничої лінії керується за допомогою розробленого додатку, що функціонує на основі платформи Arduino. Перевагою автоматизації $є$ збільшення швидкості виробництва та зменшення участі людини у виробничому процесі. Таким чином досягається збільшення якості та зменшення можливих помилок, що можуть виникати внаслідок дії людського фактору. Недоліком автоматизованих систем є складна виробнича конфігурація обладнання. Таким чином, подібні системи досягають найбільшої ефективності при масовому виробництві, коли не має необхідності у постійній зміні налаштувань системи.

Ключові слова: Arduino, автоматизація, виробнича лінія, сенсор, кроковий двигун.

INTRODUCTION. Industrial automation is a major part of every manufacturing industry. The level of industry is constantly rising. Demands for product quality and quantity are ever higher, and therefore automation is undergoing new innovations. More complex processes are being developed for the production of complex components.

Automation is a technology by which a process or procedure is performed with minimal human assistance. It is the use of various control systems to operate equipment with minimal or reduced human intervention. The benefit of automated systems lies in the acceleration of production times and the reduction of production costs. Another advantage is that it replaces hard, physical or monotonous work. In addition, machines can perform tasks that take place in a 
hazardous environment. Therefore, the development described in this article is focused on the implementation of a part of the automatic line, which provides storage and transport of workpieces and subsequent fixing of the selected workpiece for the needs of CNC milling.

Design of the hardware part of the automated production line

It includes selected components and their description, for the implementation of the production line and also the design of the mechanical and electrical part of the automated production line.

Arduino Mega 2560 is a microcontroller board based on ATMega2560. It has 54 digital input / output pins (14 of which can be used as PWM outputs), 16 analog inputs, 4 UARTs (hardware serial ports), $16 \mathrm{MHz}$ crystal oscillator, USB connection, power connector, ICSP, and reset button. Arduino Mega 2560 is suitable for this work due to its ease of use and handling. It is compatible with various superstructures and components. For extensions, there are libraries that make it easier to work with writing software. That's why Arduino was chosen as the control component to control the production line model. The Arduino Mega 2560 is also suitable due to its input-output pins, to which the components forming the automated part of the production line are connected.

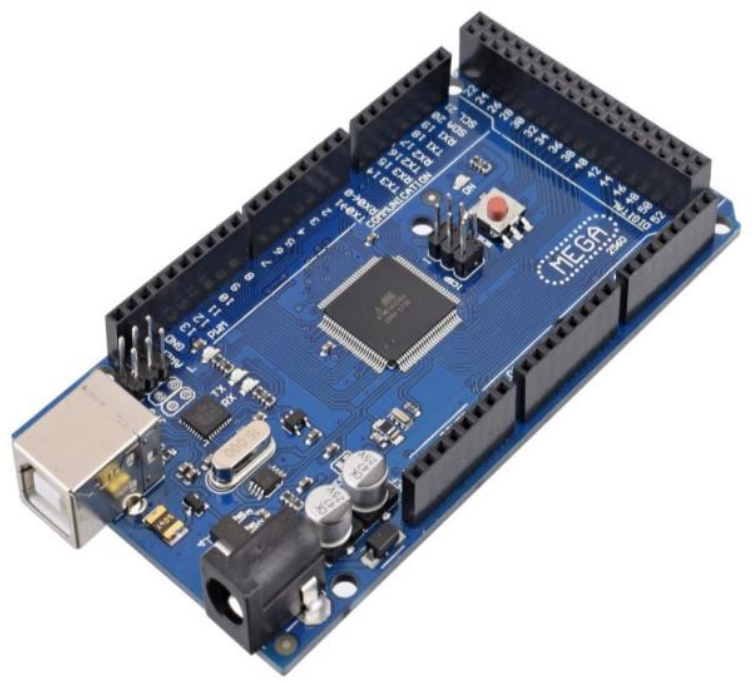

Figure 1 - Arduino Mega 2560

Another component is the CNC shield V3. It is used to control 4 stepper motors using 4 pieces of removable stepper motor board A4988. Each axis has 3 jumpers that can be set to configure microstepping for the A4988 controller board, whose output capacity limit is up to $35 \mathrm{~V}$ and $2 \mathrm{~A}$. The controller allows to control one bipolar stepper motor up to an output current of 2 A per coil, such as NEMA 17. Using this board for the Arduino with a suitable combination of motors, it is possible to create all kinds of automated movements in the project, such as linear movement, rotation of the threaded rod, and rotation of the ring with magazines. This superstructure is compatible with Arduino board without the use of any connecting cables.

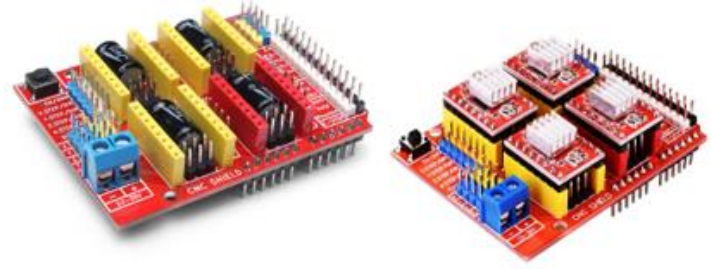

Figure 2 - CNC shield

CNC shield V3 is an open source hardware used to control stepper motors. Allows you to control 4 motors simultaneously. It uses removable A4988 stepper controls. Stepper motors are connected via 4-pin connectors. Its supply voltage is $12-36 \mathrm{~V}$.

The stepper motor is ideal for projects requiring controlled rotation. The 42BYGHW609 stepper motors used are designed according to the NEMA 17 standard. These motors are compatible with a wide range of 3D printers. They have the right torque to handle the motion requirements of a $3 \mathrm{D}$ printer. Stepper motors are often used in CNC machines. They are used to drive the axes individually or in pairs. The main feature that makes them so special is the ability to precisely control the degree of rotation. Each motor is connected to a driver board that powers and controls them. These motors are compatible with A4988 controllers. We used bipolar hybrid engines in our project. Their use is mainly in projects where it is necessary to control not only the speed of the rotor, but also its position. In the automated part of the production line when rotating the ring with magazines, it is necessary to know the number of steps, and thus the exact angle of rotation of the ring, according to the choice of a specific workpiece size. It is also necessary to know the required number of steps of the vice control motor. Fig. 3 shows the stepper motors used to control the movements of the automated system.

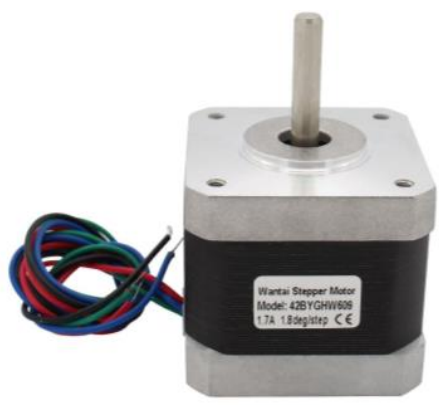

Figure 3 - Stepper motor

MH Sensor Series contains TCRT5000, it is an infrared distance sensor, route tracking sensor. The IR sensor contains four pins. The GND pin must be connected to the GND pin on the Arduino board. The same applies to the VCC pin, which must be connected to the $5 \mathrm{~V}$ pin of the Arduino board. Furthermore, pin A0 and D0 of the IR sensor must be connected to the Arduino board. Pin A0 provides information in the form of an analog value of the measured distance between the sensor and the obstacle. Pin D0 is a digital pin that goes 
from logic "0" to logic "1" if the analog value is greater than or equal to a specific value. This can be set using the blue trimmer of the infrared sensor. Fig. 4 shows a schematic connection of a motion sensor.

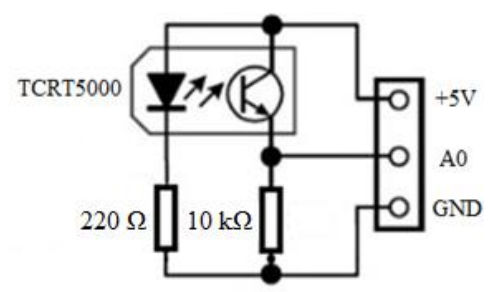

Figure 4 - Motion sensor wiring diagram

\section{Electrical design of system}

This part includes the wiring of the components and the block diagram of the wiring of a part of the automated production line. It consists of electrical components that were used in the implementation of the line. The direction of the arrow indicates the parent and child components. The computer-controlled Arduino board is controlled by a CNC shield to which three motors are connected. It also controls the sensors that send the current value of the measured object distance back to the Arduino processor.

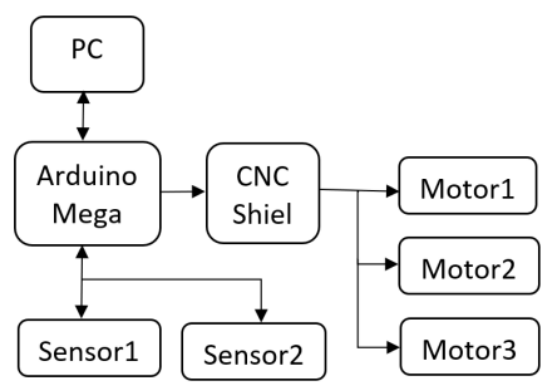

Figure 5 - Block diagram of a part of an automated production line

The CNC shield is designed so that its dimensions correspond to the size of the Arduino board and it is possible to connect the pins directly to the Arduino pins. The superstructure for CNC contains three controllers, to which three motors are connected for possible handling work in three axes.

Digital output signals are also generated for these three motors. X / Y / Z.STP means a step pulse for rotating the motor shaft in these three axes for each motor separately. X / Y / Z.DIR is the direction of axis movement for motors. X / Y / Z.LM indicates the limit of motor movement along the $\mathrm{X}, \mathrm{Y}$ or $\mathrm{Z}$ axis. The Enable pin connected to the Arduino D8 digital pin enables or disables motor stepping. Spindle Enable and Spindle direction connected to Arduino digital pins, pin D12 allows enable and pin D13 determines the direction of the shaft. Four analog Arduino pins are also used, pin A0 can be used to create an interrupt, pin A1 is used to hold the feed, A2 starts the start of the cycle and finally A3 is the coolant clearance.
Table 1 - Outputs and inputs of a CNC shield connected to the Arduino

\begin{tabular}{|l|c|}
\hline \multicolumn{1}{|c|}{ CNC shield } & Arduino Mega 2560 \\
\hline X.STP & D2 \\
\hline Y.STP & D3 \\
\hline Z.STP & D4 \\
\hline X.DR & D5 \\
\hline Y.DR & D6 \\
\hline Z.DR & D7 \\
\hline Enable & D8 \\
\hline X.LM & D9 \\
\hline Y.LM & D10 \\
\hline Z.LM & D11 \\
\hline Spindle enable & D12 \\
\hline Spindle direction & D13 \\
\hline Abort & A0 \\
\hline Hold & A1 \\
\hline Resume & A2 \\
\hline Coolant & A3 \\
\hline Reset & RESET \\
\hline $3,3 \mathrm{~V}$ & $3,3 \mathrm{~V}$ \\
\hline 5V & $5 \mathrm{~V}$ \\
\hline
\end{tabular}

The A4988 controller has a total of 16 pins and connects directly to the CNC shield in prepared socket rails. You can see an illustration of the controller in Fig. 6.

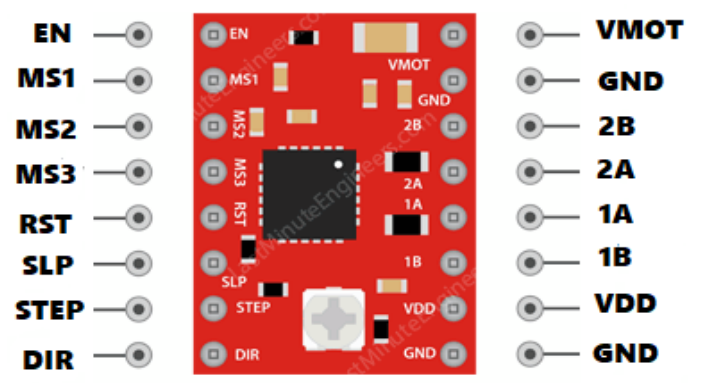

Figure 6 - Driver A4988

VDD and GND are used to control internal logic circuits, which can be $3 \mathrm{~V}$ to $5.5 \mathrm{~V}$. VMOT and GND supply voltage to the motor, which can be from 8 to $35 \mathrm{~V}$. The A4988 controller has stepping, which means that it allows the placement of intermediate steps. This is achieved by supplying the coils with medium current levels. By setting the appropriate logic levels on pins MS1, MS2 and MS3, we can set the microstepping value. The STEP input controls the motor steps. Each "HIGH" pulse sent to this pin steps the motor according to the number of steps set by pins MS1, MS2 and MS3. The faster the pulses, the faster the motor rotates. The DIR input controls the direction of motor rotation. By setting the value "HIGH" to this pin, the motor will rotate clockwise, at the value "LOW" it will rotate 
counter-clockwise. The SLP pin is active at the "LOW" level. This means that at this value, the driver goes into sleep mode, thus minimizing energy consumption. RST is also active at the "LOW" level. At this value, all STEP inputs are ignored until it reaches the "HIGH" level. The output channels of the motor controller A4988 are divided by pins 1 B, 1 A, 2 A and 2 B. Any bipolar stepper motor with a supply voltage of $8 \mathrm{~V}-35 \mathrm{~V}$ can be connected to these pins. Each output pin on the module can supply up to $2 \mathrm{~A}$ to the motor. However, the amount of current supplied to the motor depends on the system power setting, cooling system, and current limit. Excessive energy dissipation results in an increase in temperature, which can exceed the maximum value and damage the controller. Although the A4988 controller has a maximum current of 2 A per coil, the chip supplies approximately $1 \mathrm{~A}$ per coil without overheating. Cooling is required to reach more than 1 A per coil.

The motors are connected to the A4988 controller. Pins $1 \mathrm{~B}, 1 \mathrm{~A}, 2 \mathrm{~A}$ and $2 \mathrm{~B}$ are used to power the motor coils. Before using the motor, we must limit the maximum amount of current flowing through the step coils and prevent it from exceeding the rated motor current. There is a small potentiometer on the A4988 that can be used to adjust the resistance. It is advisable to set the resistance so that the voltage on the A4988 controller is higher than calculated. The rated motor current is 1.7 A per phase. It is necessary to set the limit of the reference voltage $V_{r e f}$ on the potentiometer using the formula:

$$
V_{\text {ref }}=\frac{I_{n}}{2}=\frac{1.7 \mathrm{~A}}{2}=0.875 \mathrm{~V} .
$$

The optical reflection sensor is connected to two power outputs. One output is used to connect to the analog input of the Arduino board. The sensor works with values that are converted to analog in the Arduino processor.

\section{Design of mechanical parts}

This chapter describes the design of an automated production line using Fusion 360.

The ring located on the rotating part of the motor is used as a magazine for workpieces. These are stored in holders. The functionality of the magazine ring consists in rotating by the required angle, according to the size of the workpiece by the operator. The magazines allow you to store 4 different dimensions, it is possible to place workpieces with dimensions of $25 \times 30 \times 7$, $30 \times 30 \times 7,35 \times 30 \times 7$ and 40x30x7. The lower part of the ring has a extended for the motor rotor, which ensures its good stability. A slider is placed under the magazine, the function of which is to slide the workpieces out of the magazine. From the top of the ring, the holes are prepared for screws that will place the walls of the ring container. A cut-out is made in the lower part of the circle, shown in the figure, through which the runner returns to his basic position. In Fig. 7 we can see a circle with magazines and workpieces inserted in the magazines.

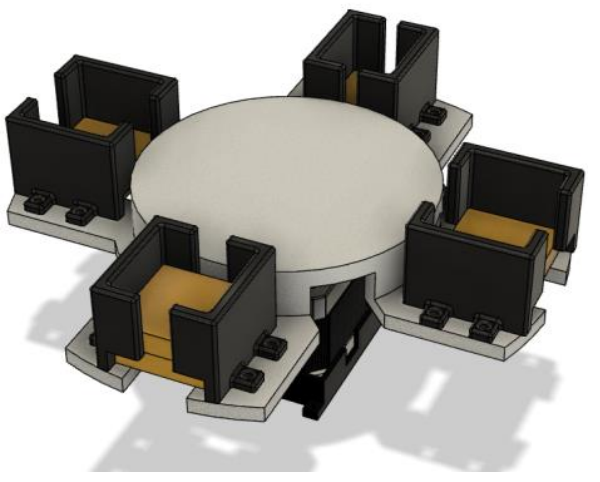

Figure 7 - Circular magazine with workpieces

Another designed part was the slider and the slider track. The purpose of the runner is to pull the workpiece out of the magazine and then transport the workpiece to the vice, which clamps it. After clamping, the necessary operations are performed to machine the workpiece, and following the release of the vice, the slider transports the workpiece to the end of the path and it falls into the collecting container. The slider is designed in an $\mathrm{L}$ shape. The runner has a rectangular hole on the back. This is used to attach the conveyor belt, which is attached to the slider. The belt passes above and below the track and its ends are connected and attached directly to the slider. The slider track is fixed with screws and is located in front of the motor, on which the ring with the magazine is placed. The path through which the slider passes can be seen in Fig. 8. It has a cut-out in its upper part in which the slider moves.

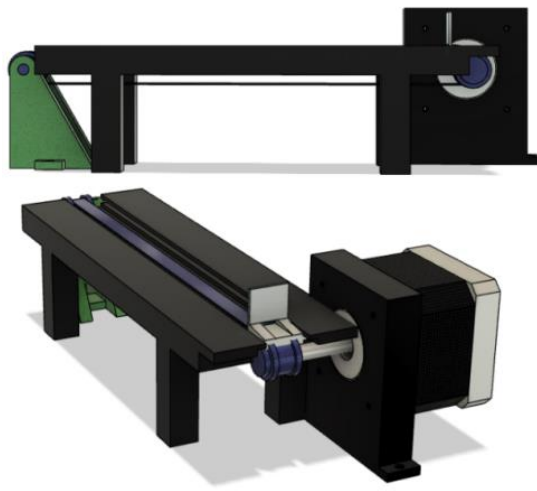

Figure 8 - Slider and slider path

The next part of the production line is the vice. It consists of two jaws. These have three holes, through one hole in the middle of the jaws passes a threaded rod. They have a screwed-on component on the back, which has a hexagonal hole. A stainless-steel nut with dimension M6 is inserted into this hole. The other two holes serve for the guide rods so that the jaws do not rotate with the rotation of the threaded rod, which is formed by a thread with a size of $6 \mathrm{~mm}$. The threaded rod is divided in half with opposite threads. One end of the rod is connected via a jumper to the motor rotor and the other end of the rod is inserted into a stop for better stability of the rod. When the motor shaft rotates 
clockwise, they approach each other and, conversely, when the rotor rotates counter clockwise, they move away from each other.

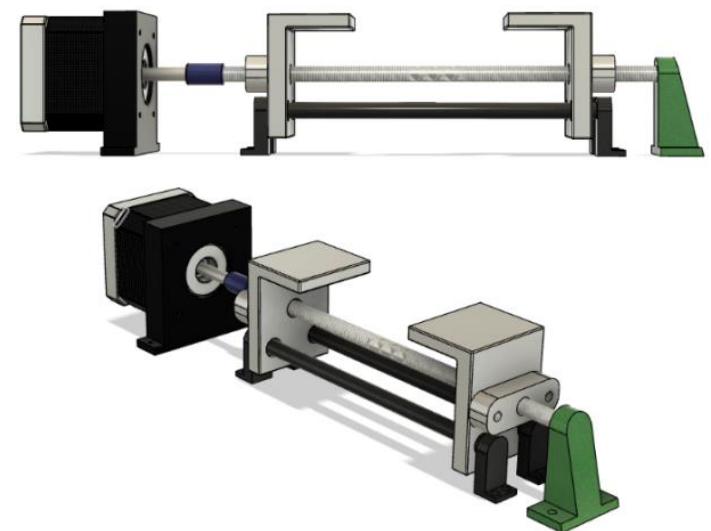

Figure 9 - Vice

The created line consists of three parts. The first part is a circular magazine attached to the motor shaft in which the workpieces are located. The next part consists of a path taken by a belt-driven slider by means of a belt. The last part is a vice, which consists of jaws, a threaded rod attached to the motor and guide rods. The functionality of the production line consists in rotating the circle with workpieces in the magazines. When selecting the workpiece size, the circle rotates a certain number of degrees, depending on the selected workpiece. After turning the circle, the motor is started, which drives the slider by means of a belt to which it is attached. There are two sensors around the track, which are located in front of the vice. These, when motion is detected, triggers the motor to be switched off, which drives the slider and starts the motor attached to the threaded rod. The vice jaws clamp the workpiece, which is ready for machining. At the end of machining, the jaws expand and the motor-driven runner begins to move until the next sensor stops. The workpiece then falls into a collecting vessel in the next step. After detecting the movement of the sensor located at the end of the track, the motor mounted on the ring is started and the ring is turned to the position for the arrival of the runner. After turning the circle, the runner returns to the starting position.

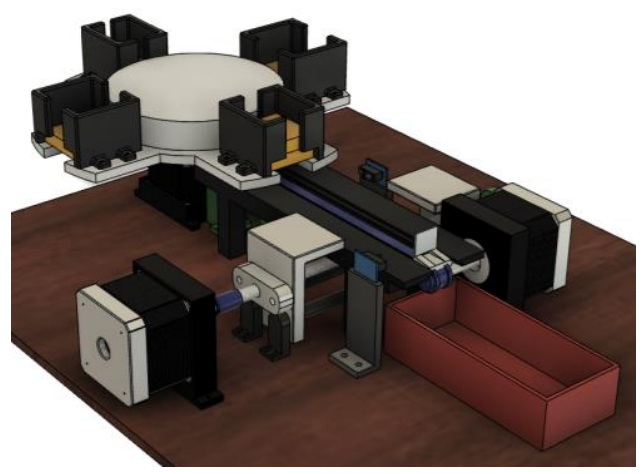

Figure 10 - Visualization of the designed part of the production line
Software part of the automated production line

A combination of two software, Arduino IDE and Visual studio, was used to design it. Arduino IDE is a program that was developed for the Arduino development environment. The program is written in Java, so we can run it on any operating system in which the Java Virtual Machine is located. The Arduino IDE development environment uses the Wring programming language and is available on the Internet. When programming and creating projects, various modules and components are used, to which the library can be downloaded, which will make the work of writing the program easier. Microsoft Visual Studio is an integrated development environment (IDE) from Microsoft. It is used to develop computer programs as well as websites, web applications, web services and mobile applications. Visual Studio provides various options and services for creating visual applications. In this case, the Windows Forms App (.NET Framework) was used. C \# was used as a programming language. It is an object-oriented programming language developed by Microsoft as part of their .NET initiative.

We do not use any additional libraries in the Arduino driver. The program consists of controlling the motors using a CNC shield and sensors that send an analog value to the Arduino processor. The program uses serial communication between the computer and the processor.

For the correct functionality of the CNC shield, it is necessary to define the Arduino output pins to which they are connected, where stepX, stepY and stepZ are the motor steps. The speed at which pulses are sent to these pins affects the speed of rotation of the motor. The constant values $\operatorname{dir} X, \operatorname{dir} Y$ and $\operatorname{dir} Z$ control the direction of motor rotation according to the value set on this pin. By setting the value "logic 1" to this pin, the motor will rotate clockwise, at the value "logic 0 " the motor will rotate counter clockwise. These pins are defined outside the void setup () initialization section and the infinite loop void loop (). These values are defined as output to the void setup () initialization sections.

The functions used to control the motors consist in sending pulses to the CNC shield. Pins 2, 3, 4 are used for this, depending on which motor we need to control. The speed of sending the "logic 1" and "logic 0" pulses affects the speed of rotation of the motor. The function contains a for () loop with an unknown variable, the value of which is chosen in the infinite loop void loop () when sending the function. The selected value corresponds to the number of engine revolutions. The position sensor works on the principle of transmitting an analog value according to the distance of the measured object. Because we use the analog pin of the sensor, we have to define the input to which we connect this sensor. In our case, the analog value from the sensor is sent via pin A8, this pin must be defined as input. The sensor transmits an analog signal. The Arduino converts it to the value from 0 to 1023 via the ADC converter. We set the value of the sensor according to the influence of the environment and the distance of the measured 
object. We will use the conditional function if (), in which we will write the condition. If the measured value is lower than the setpoint, the process in this function is performed.

Serial communication sets the data rate in bits per second. When communicating with a serial monitor, it is necessary to use one of the baud rates of the serial port. If we want to monitor the analog values of the sensor, it is possible to display these values using the Serial.print () function. We write the analog input of Arduino, the value of which we want to observe, in an empty parenthesis.

The serial monitor is also used to read incoming data from the command line using the Serial.read () command. We store the value read from the serial communication in the defined variable and then use the conditional function if () to monitor whether the variable with the stored value meets our specified condition. In case of a match, the process written in the condition is performed.

In the Windows Forms App, we created an application used to control an automated production line. Clicking the left mouse button on the "Open Port" button opens the serial communication between the Arduino and the computer. Conversely, pressing the "Close Port" button closes this communication. When the button named "" to "Workpiece 40mm" or "AUTO $M O D E^{\prime \prime}$ is pressed, with serial communication switched on, a command is sent from the processor to the Arduino to start the motor and the circle rotates according to which workpiece size we have selected. You can see the application in Fig. 11.

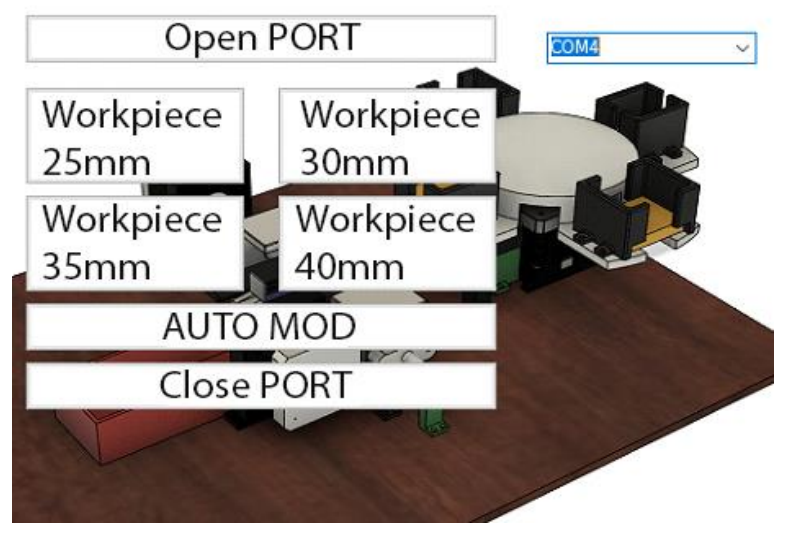

Figure 31 - System control application

Arduino can be controlled using a created application in Visual Studio using a serial port. To do this, you need to create a function and use commands for SerialPort. First you need to name and create a new serial port. Then we determine the data transfer speed of the port and add the communication port. Use the "port_name.Open()" command to open the port and the "port_name.Closed()" command to close it. With the port open, use the "port_name.WriteLine(" ")" command; we can write a command in quotation marks, which will be sent to the Arduino processor using serial communication.

\section{Realization of mechanical automated production} line parts

We had to print the individual components on a 3D printer. We designed the components in a Fusion 360 and then generated the STL file format needed to create the G-code, using the G3DMaker software. The Fig. 12 shows the STL path file for the slider and circle added to G3DMaker.

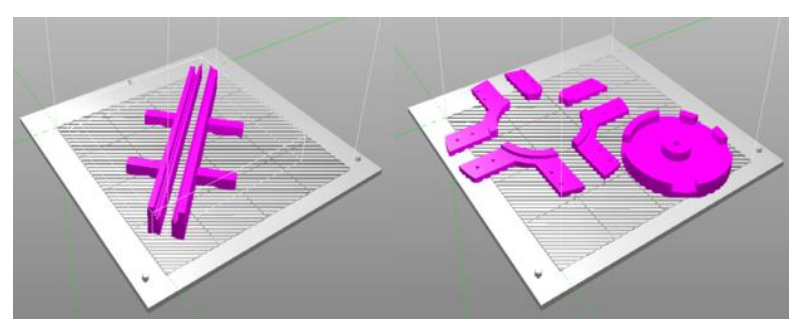

Figure 12 - G3DMaker and STL files

We can see from the picture that we had to divide these two components into two parts, because in total they could not be pushed out due to notches in the path for moving the slider and for the circle it would be necessary to add support material under the top. After adding the STL file, the next step is the G-code, which will be generated using the G-code generation button. Then we connect a $3 \mathrm{D}$ printer and we can print. After printing all the components, we started creating the model. First, it was necessary to connect parts of the track for the slider and the circle, which could not be printed as a whole. We first fastened the motor base to the base with screws, on which a circle with magazines is placed. We put the motor in it and drilled a hole for the output cables. The path for the slider is measured in the middle of the wooden base, we screwed it on the bottom. After its installation, it was necessary to assemble a vice composed of several parts. First, we fastened the component with the nut to the back of the jaws with screws. We screwed the jaws onto the threaded rod. One of the jaws contains a nut with a left-handed thread and the other with a right-handed thread. Subsequently, we inserted two guide rods into the holes on the bottom of the jaws. At their ends there are extensions for fixing the guide rods and adjusting the required height of the jaws. There is also an extension at the end of the threaded rod, which serves as an end stop and prevents the movement of the threaded rod along the X-axis. The other end of the threaded rod is attached to the motor inserted in the base via a jumper. Another base holding the motor driving the slider is located on the end side of the path for the slider, on the other side there is a component serving to tension the drive belt. The motor has a gear mounted on its shaft. It is attached to the belt on a slider, and is inserted into grooves in the track. As the motor shaft rotates, the slider moves in grooves. Sensors located on the edge of the track are insulated and inserted into metal bases. Lastly, there is a container for finished milled workpieces. 


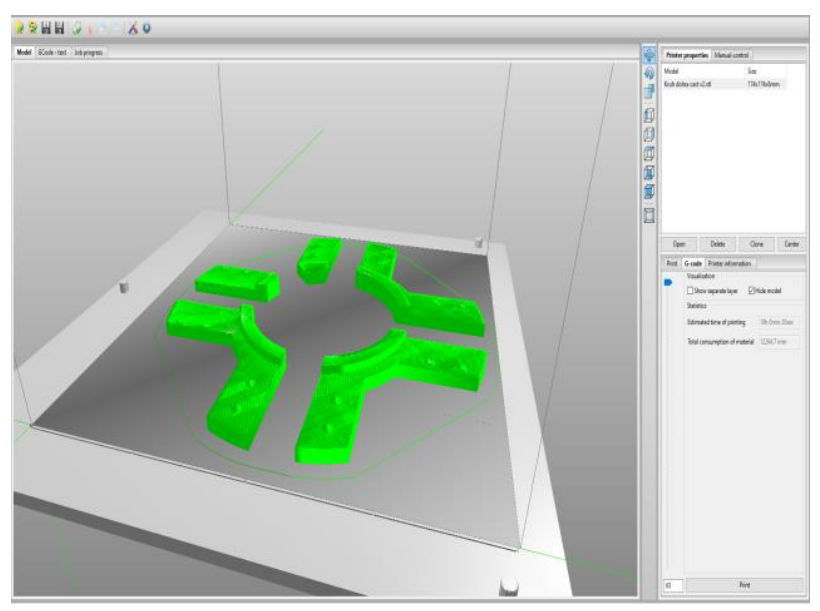

Figure 13 - Generating of G-code

\section{Method of device control}

The system control application contains seven buttons. Use the "Open Port" button to open the serial port, which can be turned off with the "Close Port" button. The four buttons called "Workpiece (dimension)" are inoperative when serial communication is switched off. When serial communication is switched on, pressing the button with the appropriate dimension starts the motor on which the hopper is mounted. It rotates at the angle where the workpiece is located. After turning the circle, the motor is started, which drives the slider by means of a belt. The workpiece placed in the magazine is extended and is moved to the first sensor, which detects the movement and stops the motor. The workpiece is located between the jaws of the vice. After stopping the engine and starting the engine controlling the vice. The threaded rod starts to rotate, bringing the jaws closer together and clamping the workpiece. For a motor that controls a vice, the exact number of motor steps required to clamp a workpiece that is ready to be machined is precisely calculated. Subsequently, the motor on which the threaded rod is connected will lower to the opposite side, this will cause the jaws to move apart. With a sufficient distance of the jaws, the motor for the slider is started again and it pushes the workpiece to the end of the path, where the sensor is located. The workpiece falls into the container. After recording the signal at the end of the path, the sensor sends a signal to the processor about the presence of the object. Subsequently, the magazine is rotated at such an angle that the runner can return to its initial position. When finished, it is possible to select another workpiece with dimensions according to the needs of the operator.

The button called "AUTO MODE" is used for automatic mode. This mode has the same principle of operation of the model with the difference that it empties the entire container automatically without the need for operator intervention.

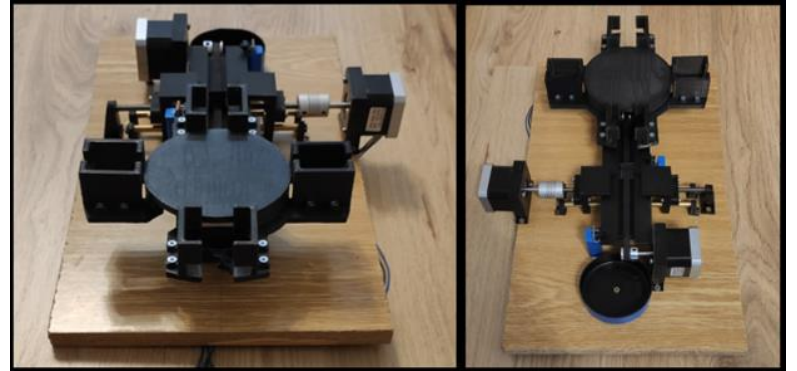

Figure 14 - Realised system

CONCLUSION. The aim of the project was to design and create a part of an automated production line, the principle of which consists in feeding workpieces and subsequent fixing of the workpiece to the vice, where the machine tool can machine the workpiece. In this work we solved the design of the hardware part in CAD software. The designed hardware was printed by $3 \mathrm{D}$ printers. The software part is solved using Arduino, which is a serial communication connected to an application created by Visual Studio.

The system in the future can be expanded with other parts, such as a workpiece feeder that will fill the bins. Most production lines include signalling showing machine operation, machine failure and readiness. The production line could include three process signals. The first at the magazine, the second for information about the movement of the slider along the path, and the last signalling could inform about the movement of the vice jaws. Another improvement for work could be a sensor that monitors the current state of the magazines and alerts you when there is a lack of workpieces, or when the capacity of the magazine is empty.

\section{REFERENCES}

1. Automatizácia v priemysle (2019). URL: https://www.haberko rn.cz/sk/detail/579/automatizaciav-priemysle-i-zaklady-line-arnej-techniky

2. Arduino Mega 2560 (2020). URL: http://www.farn ell.com/datasheets/810077.pdf

3. Delorme, Xavier, et al. (2009). Machining lines automation. Springer handbook of automation. Springer, Berlin, Heidelberg. 599-617.

4. CNC 3axis shield (2020). URL: http://www.straightru-nning.com/Xming

5. Stepper motor NEMA 17 (2020). URL: https://sparkfruit.ph/product/stephttps://sparkfruit.ph/pro duct/stepper-motor-nema-17-42byghw609/per-motornema-17-42byghw609/

6. Arduino Tutorial: IR Distance (2018). URL: https://www.mschoeffler.de/2017/11/27/arduinotutorial-ir-d-istance-line-tracing-line-tracking-sensormh-sensor-seriesky-033-tcrt5000/
7. A4988
Datasheet
(2018)
URL: https://www.alldatasheet.-

com/view.jsp?Searchword=A4988\&gclid=CjwKCAjws sD0BRBIEiwAJP5rLO4uiw0V1WRIcePv7B6woehvB1 35q7H96u7OgE8WiV6XxyiHdzfXxoC7y4QAvD_BwE

8. Fusion 360 (2019) URL: http://www.stor.sk/cadsoftware-divizia/fusion-360 


\section{ПРОЕКТИРОВАНИЕ И РАЗРАБОТКА ФИДЕРНОЙ ЧАСТИ АВТОМАТИЗИРОВАННОЙ ПРОИЗВОДСТВЕННОЙ ЛИНИИ}

\section{Б. Фечко, Т. Винсе, Л. Дарак}

Технический университет Кошице

ул. Летна, 9, г. Кошице, 04200, Словакия. E-mail: branislav.fecko@tuke.sk.tibor.vince@tuke.sk

Целью работы является проектирование и создание части автоматизированной производственной линии, предназначенной для транспортировки и обработки продукции. В статье представлены результаты исследования подходов к разработке малобюджетного прототипа автоматизированной производственной линии, управляемый микроконтроллерным устройством. В статье предложена одна из возможностей разработки автоматической производственной линии с использованием платформы Arduino ATmega2560 совместно с CNC shield V3, обеспечивающие функционирование двигателей. Для внедрения разработки использованы три шаговых двигателя и два сенсора положения. Отдельные части системы были спроектированы с помощью CAD-систем и затем распечатаны с помощью 3D-принтера. Авторы описали весь процесс разработки, начиная с компьютерного моделирования разрабатываемого устройства, проектирование аппаратной части, выбора и расчета силовых преобразовательных элементов, разработки элементов аппаратного обеспечения, разработки и внедрения низкоуровневых и высокоуровневых решений программного обеспечения, а также заканчивая экспериментальной проверкой полученных результатов. В работе был решен вопрос по проектированию аппаратной части с помощью CAD-пакетов. Спроектированное аппаратное обеспечение распечатано с помощью 3D-принтера. Решение о программном обеспечении были получены на основе использования платформы Arduino, последовательно соединеным с программным приложением, созданным в среде Visual Studio. Работа производственной линии управляется с помощью разработанного приложения, функционирующего на основе платформы Arduino. Преимуществом автоматизации является увеличение скорости производства и уменьшение участия человека в производственном процессе. Таким образом, достигается увеличение качества и уменьшение возможных ошибок которые могут возникать в результате действия человеческого фактора. Недостатком автоматизированных систем является сложная производственная конфигурация оборудования. Таким образом, подобные системы достигают наибольшей эффективности при массовом производстве, когда нет необходимости в постоянном изменении настроек системы.

Ключевые слова: Arduino, автоматизация, производственная линия, сенсор, шаговый двигатель.

Стаття надійшла 08.04.2020. 